
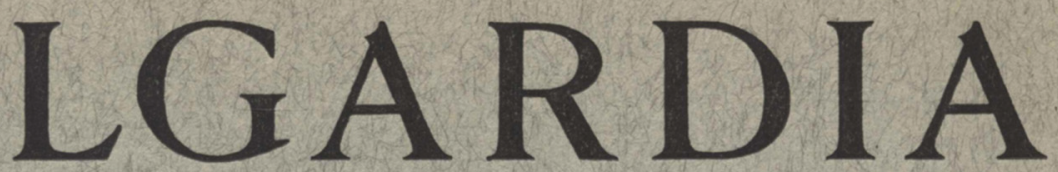

A Journal of Agricultural Science Publisbed by the California Agricultural Experiment Station

CONTENTS

NEWLY DISCOVERED LEAFHOPPER

VECTORS OF CALIFORNIA

ASTER-YELLOWS VIRUS

HENRY H. P. SEVERIN

CHARACTERS, DISTRIBUTION, AND FOOD PLANTS OF NEWLY DISCOVERED VECTORS OF CALIFORNIA ASTER-YELLOWS VIRUS DWIGHT M. DELONG AND HENRY H. P. SEVERIN

LONGEVITY OF NONINFECTIVE AND INFECTIVE LEAFHOPPERS ON A PLANT NONSUSCEPTIBLE TO A VIRUS HENRY H. P. SEVERIN 
CHARACTERS, DISTRIBUTION, AND FOOD PLANTS OF NEWLY DISCOVERED VECTORS OF CALIFORNIA ASTER-YELLOWS VIRUS

DWIGHT M. DeLONG and HENRY H. P. SEVERIN 



\title{
CHARACTERS, DISTRIBUTION, AND FOOD PLANTS OF NEWLY DISCOVERED VECTORS OF CALIFORNIA ASTER-YELLOWS VIRUS ${ }^{1}$
}

\author{
DWIGHT M. DeLONG ${ }^{2}$ and HENRY H. P. SEVERIN ${ }^{3}$
}

\section{INTRODUCTION}

FIVE LEAFHOPPER SPECIES are reported in the accompanying paper (Severin, $1947)^{5}$ as vectors of California aster-yellows virus. The insects are illustrated by colored plates in that paper. The present paper deals with the characters, distribution, and food plants of these leafhopper vectors, which belong to the genera Cloanthanus, Euscelis, Fieberiella and Chlorotettix.

\section{CLOANTHANUS ACUTUS (SAY)}

Cloanthanus acutus has not been demonstrated to be a vector of the virus, but is included here because it has been confused with other species.

The species of Cloanthanus, formerly placed in Platymetopius, have been confused in their identity for many years because an attempt has been made to determine them by color pattern alone. These species unfortunately are too similar in color to distinguish several of the common species on this basis.

After a study of the Mexican and southwestern species, DeLong (1943) used the male genital structures to distinguish them. He showed that in many cases the structures are quite different. By means of those structures he set up a neotype (1945) for one of the common eastern species, Cloanthanus acutus (Say, 1831) illustrating the genital structures (fig. 1) and describing several closely related species in the East. From these studies it is obvious that several common or economic species have been erroneously identified in the past, and it is apparent that typical C. acutus does not occur in California nor the western United States in general.

\section{CLOANTHANUS IRRORATUS (VAN DUZEE)}

Cloanthanus irroratus (Van Duzee, 1910) is a brown species with a banded vertex and an irrorate face. In length it measures from 3.5 to $4.0 \mathrm{~mm}$.

The vertex (fig. $2, A$ ) is strongly produced and angled, and its median length is a little more than one third greater than the basal width between the eyes.

In color the vertex is dark brown with a wedge-shaped apical spot. A series of short pale longitudinal lines form a broken transverse band before the eyes. The base is also pale. The pronotum is brown with five pale longitudinal lines.

\footnotetext{
${ }^{1}$ Received for publication March 23, 1946.

2 Professor of Entomology, Ohio State University, Columbus, Ohio.

3 Entomologist in the Experiment Station.

4 The authors wish to express appreciation to R. V. Hershberger, Ohio State University, who assisted with the illustrations.

"See "Literature Cited" for citations, referred to in the text by author and date.
} 
The scutellum is pale, the basal angles are orange. The elytra are rather sparsely irrorate forming several pale areas. The face is pale brown, irrorate with darker brown.

The female last ventral segment has the posterior margin produced in a broadly rounded shape.

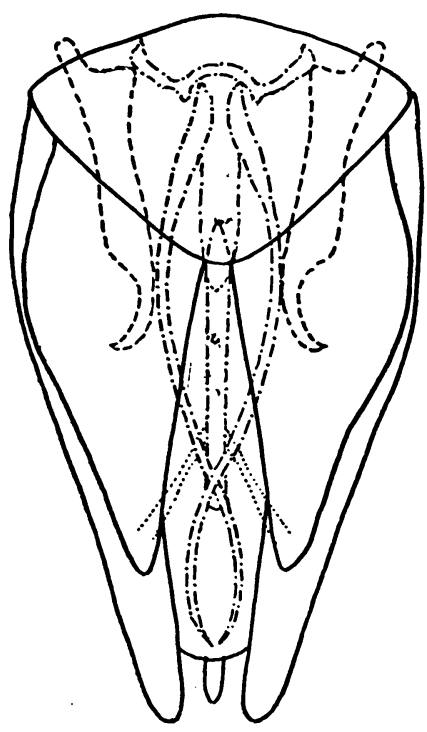

$A$
Fig. 1.-Cloanthanus acutus (Say): $A$, ventral view of male genital structures; $B$, lateral view of male genital structures.

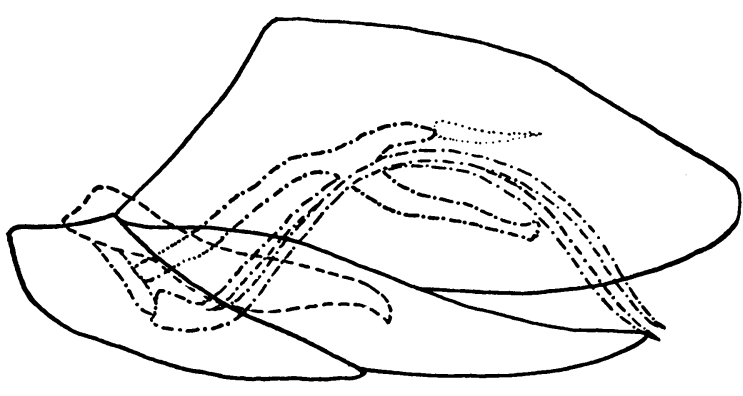

$\boldsymbol{B}$

The male genital plates are triangular (fig. 2, B). The style has a fingerlike apical process which curves outwardly (fig. $2, C$ ). The aedeagus is broadly U-shaped with a basal stem. The apical portion of the stem has a pair of processes which are bent anteriorly.

The female segment is not different from that of most of the species of the genus. The male, however, is unique in the structure of the genital pieces, and the lateral view of the aedeagus will separate it at once from any of the other described North American species. A recently described Mexican species, Cloanthanus apertus DeLong (1943), is probably nearest in type of aedeagus. Of those species occurring in the United States C.torridus (Ball, 1916) is probably nearest in genital structure.

Geographic Range.-In his original description Van Duzee (1910) cited this species from Chino, Riverside, Pasadena, and San Diego, California; Phoenix, Arizona; and Tia Juana, Mexico. More recent records show its range extending to the states of Nuevo Leon and San Luis Potosi, Mexico (DeLong, 1943).

Distribution and Food Plants in California. During this study it has been collected in the following localities in California: 
Riverside County: At Arlington on May 21, 1941, 2 females were obtained from an alfalfa field by N. W. Frazier.

Kern County: On December 21, 1941, at Arvin, a few adults were captured in miscellaneous sweepings by N. W. Frazier. The host plant is unknown.

Fig. 2.-Cloanthanus irroratus (Van Duzee): $A$, dorsal view of head, pronotum and scutellum; $B$, ventral view of male genital structures; $C$, lateral view of male genital structures.

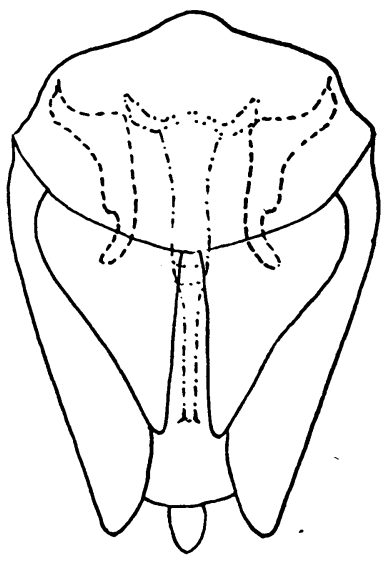

B

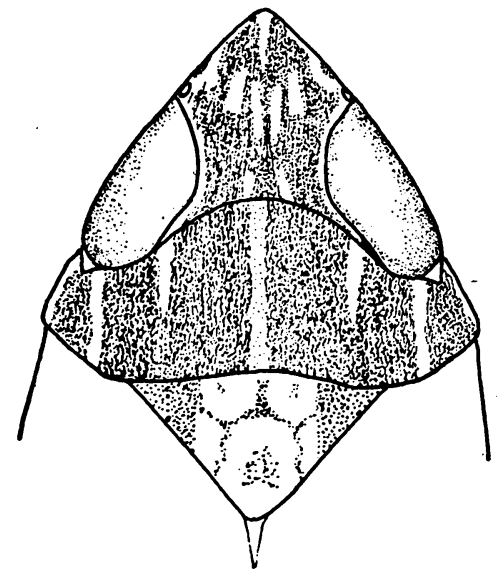

$A$

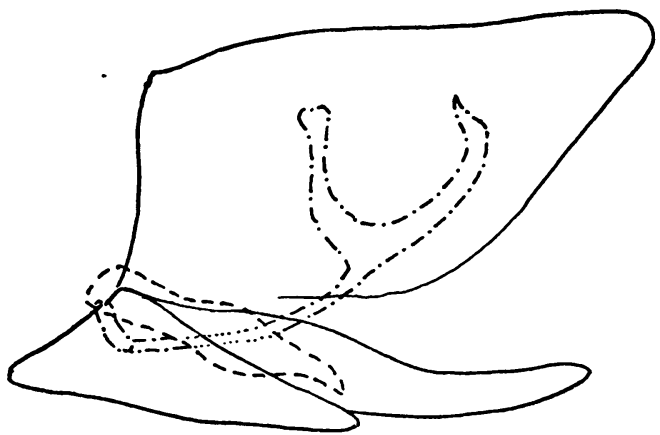

C

Madera County: At Madera on October 9, 1941, several adults were collected in an alfalfa field by H. H. P. Severin.

Sacramento County: In a locality known as Sacramento Pocket on September 12 and 18, 1941, adults were commonly taken on wild licorice, Glycyrrhiza lepidota, by H. H. P. Severin.

Sonoma County: Adults were caught in sweepings of mountain grape, Vitis rupestris, and California blackberry, Rubus vitifolius, at Triniti (in foothills near Cloverdale), May 8, 1940, by N. W. Frazier.

San Mateo County: On September 19, 1941, at Montara, a few adults were collected on weeds by H. H. P. Severin. 


\section{CLOANTHANUS DUBIUS (VAN DUZEE)}

The leafhopper Cloanthanus dubius (Van Duzee) is given specific ranking in this discussion. Superficially it resembles $C$. acutus rather closely in form, color, size, and markings. Several years ago when it was named by Van Duzee

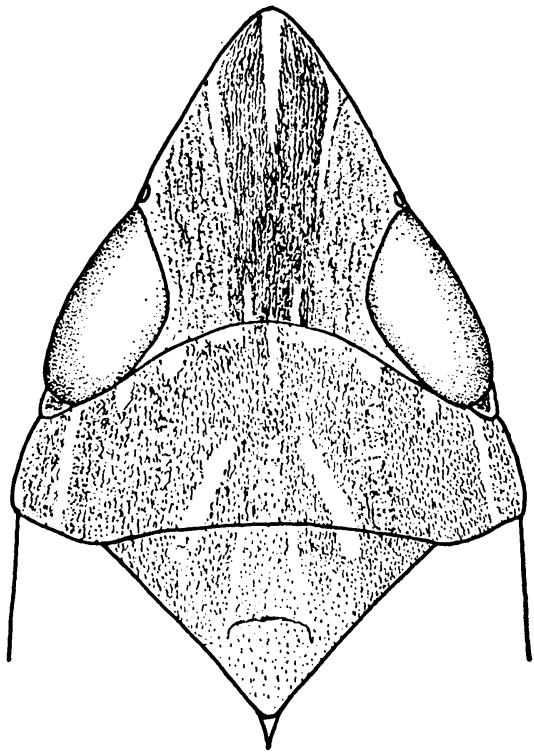

$A$

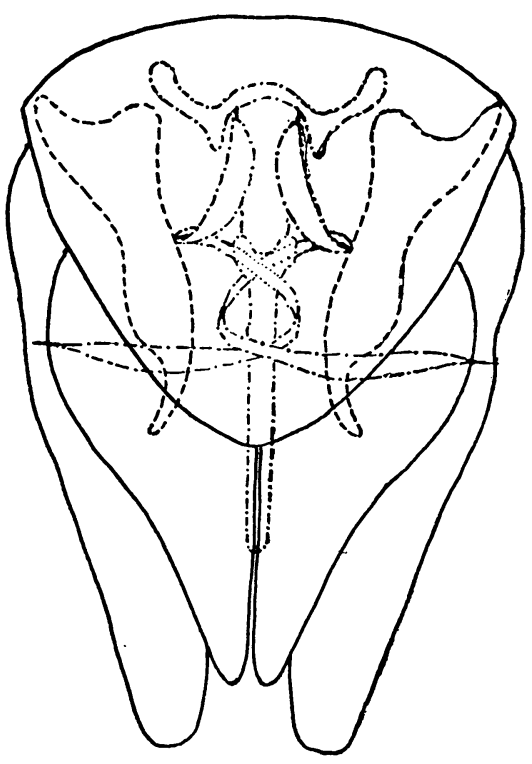

B
Fig. 3.-Cloanthanus dubius (Van Duzee): $A$, dorsal view of head, pronotum, and scutellum; $B$, ventral view of male genital structures; $C$, lateral view of male genital structures.

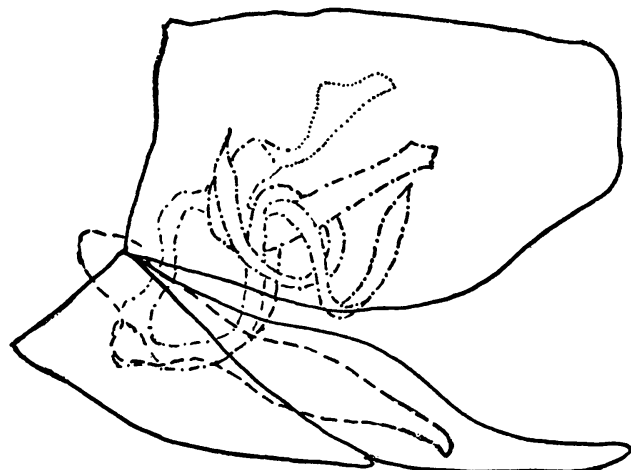

C

$(1910,1917)$, he placed it as a variety of $C$. acutus and did not take space to describe it. Since more detailed study has been made of speciation and characters to designate species, it seems advisable to give it specific ranking.

Cloanthanus dubius resembles $C$. acutus in form and color-dark brown with a pale face-but has distinct male genitalia (fig. $3, B, C$ ). Its length is $5 \mathrm{~mm}$. 
The vertex is strongly produced and sharply angled (fig. $3, A$ ). Its median length is about one and one half times as great as the basal width between the eyes.

In coloration the intensity varies from pale brown to dark brown. The male is usually darker in color than the female. The color is formed by rather closely spaced brown mottlings or rows of irrorate spots. The vertex in the male is dark brown with three slender white longitudinal stripes, one at the apex extending about one third the distance to base and one on either side about half way from the apex to the eye, extending slightly obliquely toward base. In the female the vertex appears to have a broad dark median longitudinal band because the coloration is darker between the two lateral pale lines. The pronotum is brown with traces of five pale longitudinal lines. The scutellum has the basal angles usually darker, the central portion somewhat mottled with pale spots. The elytra have pale round areolar spots in the base or apex of cells on the corium, clavus, or in the apical or anteapical cells. The face is pale and darker just beneath margin.

The female last ventral segment has the posterior margin produced in a broadly rounded shape.

The male plates are rather short, rather broad at base, and triangular. The style is elongate, narrowed at about one third its length, and more deeply excavated on outer margin near apex to form a rather long slender fingerlike apex, which curves outward. The aedeagus is composed of a dorsal U-shaped portion and a pair of ventral processes which are long and vermiculate. The dorsal portion is rather broad, curved at base, the ventral piece of which is rather blunt at apex. The dorsal piece is much shorter and attached to a dorsal membranous portion. The ventral paired processes are long, normally curved about the ventral piece of the dorsal portion, broadened to form narrow bladelike structures on their apical fourth, and are sharply pointed at the apex.

As compared with the male genital structure of Cloanthanus acutus, the most striking differences are in the ventral piece of the dorsal portion and paired processes of the ventral portion. In $C$. acutus these paired processes are long and narrow, not broadened apically, and extend to the apex of the pygofer without being curved around the dorsal portion of the aedeagus.

Geographic Range. This species seems to be confined to the West Coast states and probably to California. It has been cited, apparently in error, from Quebec by Van Duzee (1908) and from Tennessee by DeLong (1916).

Distribution and Food Plants in California. Van Duzee (1914) reports this variety of leafhopper as not uncommon on the chaparral at Alpine and elsewhere in San Diego County.

N. W. Frazier collected this variety of leafhopper on pasture grasses and weeds in the following localities:

Sonoma County: Triniti, June 25, 1939; May 12, 1940; March 28, 1942; February 13, April 7, and June 4, 1943; and June 8, 1944.

Napa County: Dry Creek School, June 2, 1942; February 13, 1943. 


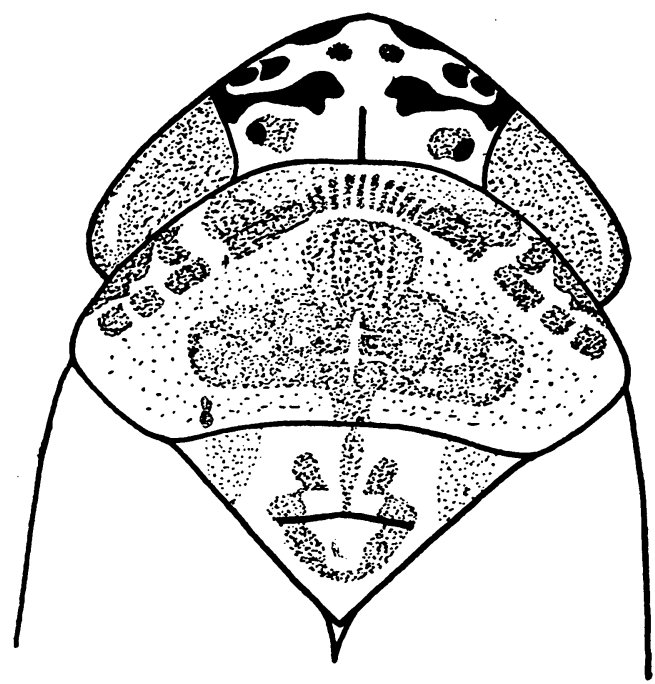

A

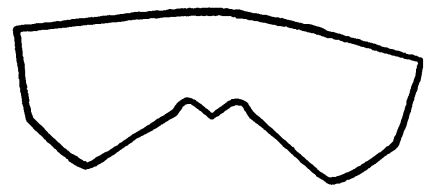

$\boldsymbol{B}$

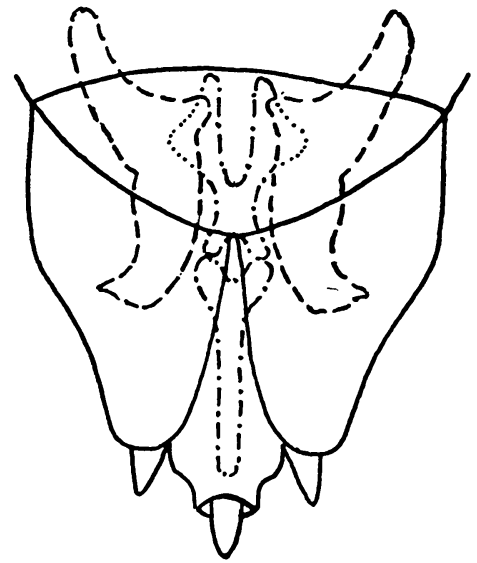

C

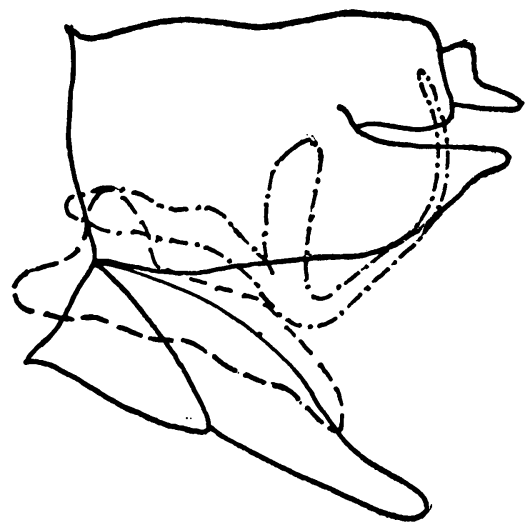

$D$

Fig. 4.-Euscelis maculipenis DeLong and Davidson: $A$, dorsal view of head, pronotum, and scutellum; $B$, ventral view of ninth female abdominal segment; $C$, ventral view of male genital structures; $D$, lateral view of male genital structures.

\section{EUSCELIS MACULIPENIS DeLONG AND DAVIDSON}

Euscelis maculipenis DeLong and Davidson (1934) is a rather robust species with a bluntly produced head which is marked with brown spots. It measures 5.0 to $5.5 \mathrm{~mm}$ in length.

The vertex (fig. $4, A$ ) is bluntly produced, about one third longer in the 
middle than next the eyes and is more than one third wider between the eyes than the median length.

The color is somewhat variable in intensity. Usually there is a row of four black spots just above the margin and a transverse spot on either side, sometimes divided, extending from the eye above the ocellus almost to the middle of the vertex. The pronotum is marked with black spots and transverse striae. The elytra are marked with small dark brown spots, especially paralleling or between the veins. These markings are more intensified in some specimens. The apices of the elytra are infuscated.

The last ventral segment of the female (fig. $4, B$ ) has a posterior margin which is broadly excavated from the rather prominent lateral angles to a median broad, slightly produced tooth, which is black-margined.

The male valve (fig. $4, C$ ) is bluntly triangular and the plates are rather broad, blunt, and rounded at the apices. The styles are rather elongate with broad blunt apices and a sharp-pointed spinelike projection on the outer apical margin. The aedeagus is rather slender and U-shaped. The basal third is thickened and bent dorsally, from the base of which the more slender portion slopes caudally and dorsally to the anal tube (fig. $4, D$ ).

Geographical Range. This species was originally described from specimens from Idaho. It has since been collected in Oregon and California.

Distribution and Food Plants in California. The first population of this leafhopper was collected by J. H. Freitag in a depleted, grassy, alfalfa field near Milpitas on January 8, 1943. Nymphs were commonly taken in this alfalfa field in the spring, but during the summer the adults flew to other food plants. During 1943 to 1945 adults were captured by H. H. P. Severin in the spring, summer, and autumn in vegetable fields in South San Francisco on the following economic plants: celery, Apium graveolens var. dulce; common dandelion, Taraxacum vulgare; endive, Cichorium endivia; lettuce, Lactuca sativa; garden, table, or red beets, Beta vulgaris; Swiss chard, B. vulgaris var. cicla; and New Zealand spinach, Tetragonia expansa. Nymphs and adults were commonly collected on the following herbs: narrow-leaf sage, Salvia officinalis; rosemary, Rosmarinus officinalis; and sweet marjoram, Majorana hortensis. The adults were often taken on Artemisia vulgaris growing along the Russian River near Geyserville and the Napa River near St. Helena and Larkmead.

\section{FIEBERIELLA FLORII (STÅL)}

Fieberiella florii (Stål) (1864) was formerly called Philipsius atropunctatus DeLong (1923). It is a broad, flat-headed species, the upper surface of which is almost completely covered with small round black "pepper" spots. In length it measures 7.0 to $7.2 \mathrm{~mm}$.

The vertex (fig. $5, A$ ) is flat and one and one half times as wide between the eyes as the median length. The anterior edge is sharp. The elytra are rather broad, opaque, and flaring at the apices. The veins are rather obscure, and the appendix is wanting. 


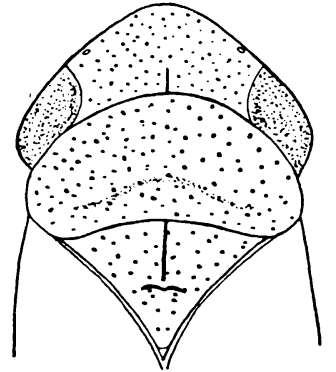

$A$

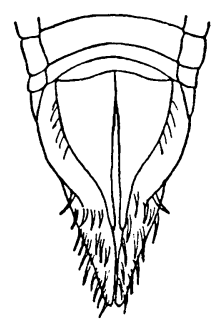

C

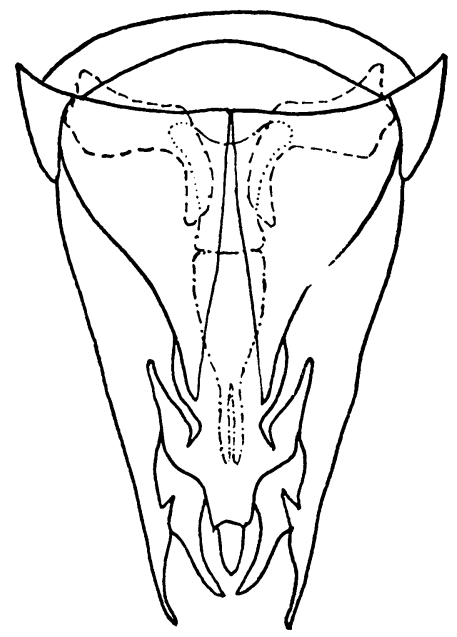

$E$

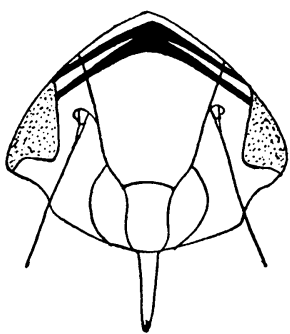

$B$

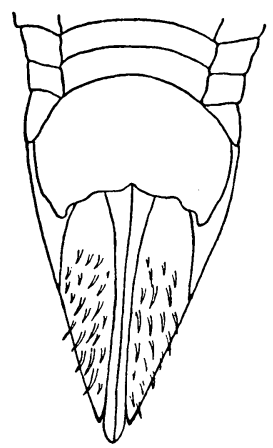

$D$

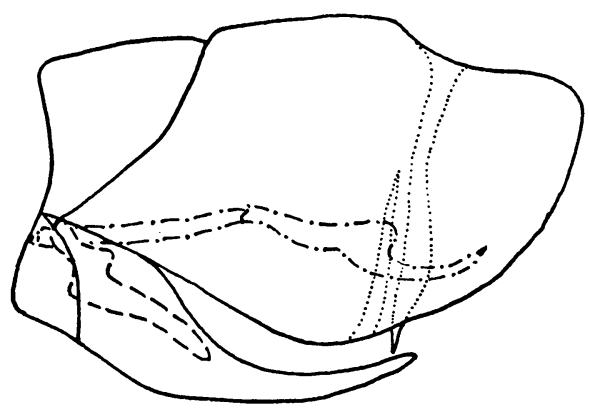

$F$

Fig. 5.-Fieberiella florii (Stål): $A$, dorsal view of head, pronotum, and scutellum; $B$, ventral view of head showing face; $C$, ventral view of posterior portion of male abdomen showing the valve, plates, and pygofer; $D$, ventral view of posterior portion of female abdomen showing ninth segment, pygofer, and ovipositor; $E$, ventral view of male genital structures; $F$, lateral view of male genital structures. 
The vertex, pronotum, scutellum, and elytra are dull yellow, and rather densely and finely irrorate with round black spots. The veins are slightly brown and the apical veins are broadly margined with dark fuscous. The face (fig. $5, B$ ) is yellowish with two heavy black bands, sometimes fused, just below the margin of the vertex. In the female the venter is white, the last ventral segment and pygofer brownish.

The female last ventral segment has rather prominent rounded lateral angles, between which the posterior margin is sinuately concave with a very shallow central notch (fig. $5, D$ ).

The male plates (fig. 5, $C$ ) are elongate, triangular, longer than the combined width at the base and are narrowed to long acute attenuated apices. The styles are short, the apical third is rather narrow and curved outward. The aedeagus is thickened at the middle and narrowed on the apical third to form a pair of proximal fingerlike processes (fig. 5, E). There are two pairs of long spines on the pygofer. The longer pair are bladelike in appearance and extend from the dorsal margin to the ventral margin of the pygofer (fig. $5, F$ ). The shorter pair extend dorsally from the ventral margin of the pygofer just beyond the middle of the aedeagus.

Geographical Range. This species was described from Europe and has apparently been imported into the United States upon ornamental plants. It was first found along the eastern coast and was redescribed by DeLong (1923) from Connecticut. It has since been found in Ohio, Illinois, and more recently in California. In the eastern states it is common on certain perennial ornamental plants.

Distribution and Food Plants in California. Napa County: The first population of this leafhopper was collected by J. H. Freitag on California privet (Ligustrum ovalifolium) growing as a hedge along the roadsides of the Beaulieu estate at Rutherford on August 9, 1944. Adults were captured by H. H. P. Severin on California privet growing on the Beaulieu estate on August 31, 1945 , and on another hedge (L. nanum var. compactum) at St. Helena on the same date. On September 6 and October 4, 1945, and July 29 and August 9, 1946, adults were taken on classic myrtle (Myrtus communis) and on Cotoneaster pannosa growing on the grounds of the Napa Junior College. Nymphs were commonly collected on these host plants during April, May, and June but were rarely taken on these same host plants during the autumn. The leafhopper may overwinter in the egg stage in California, or the adults may fly to other food plants.

\section{CHLOROTETTIX SIMILIS DeLONG}

Chlorotettix similis DeLong (1919) is a pale-green, broad-headed species similar in appearance to $C$. unicolor, a common northeastern species. In length it measures from 6.5 to $7.5 \mathrm{~mm}$.

The vertex (fig. $6, A$ ) is broadly rounded and longer at the middle than next to the eyes. The width between the eyes is more than twice the median length. 

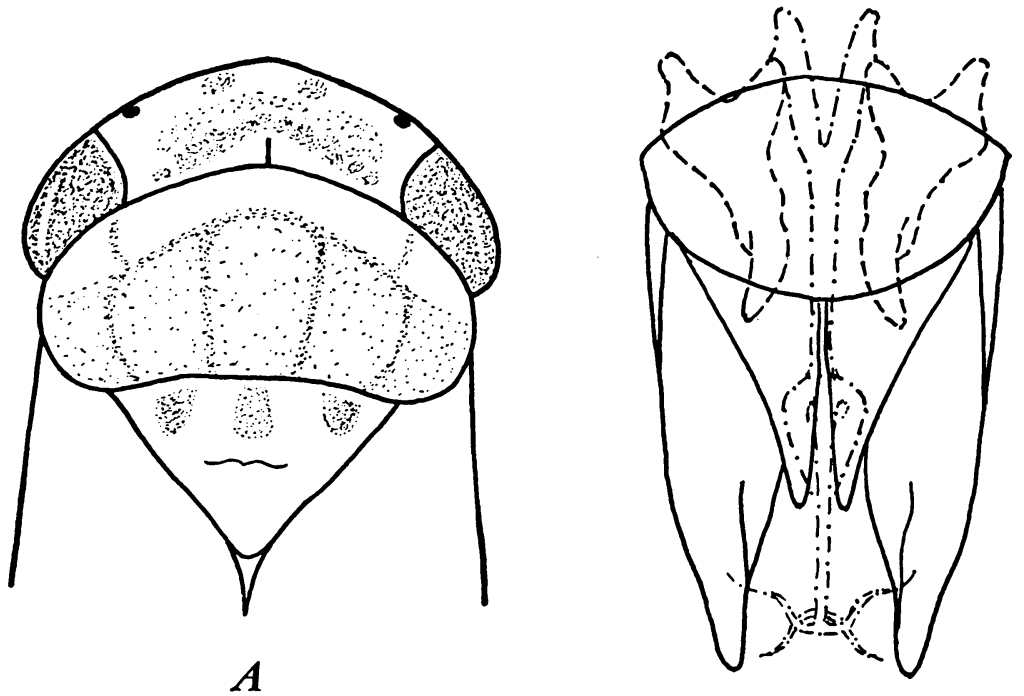

C
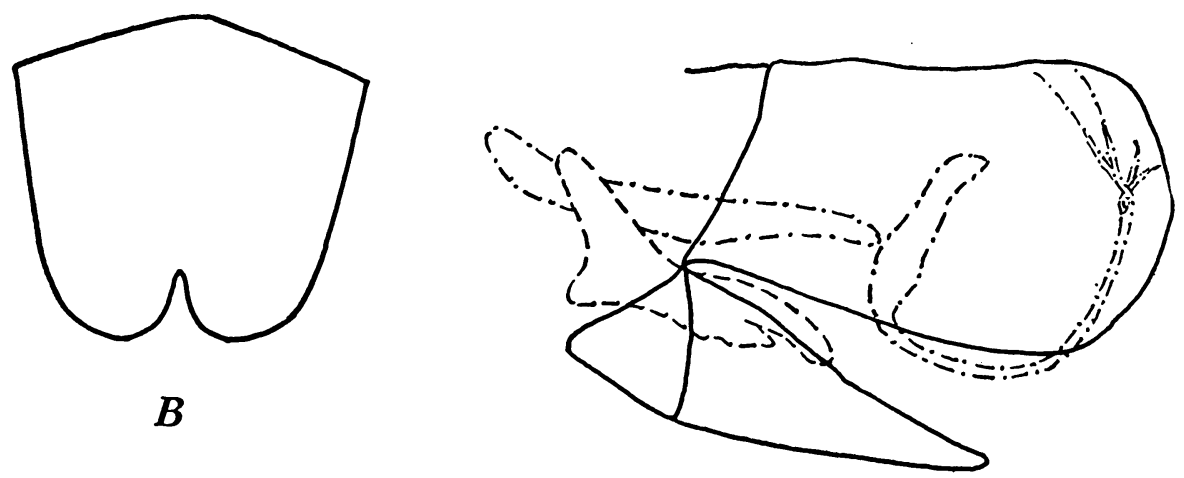

$D$

Fig. 6.-Chlorotettix similis DeLong: $A$, dorsal view of head, pronotum, and scutellum; $B$, ventral view of ninth segment of female; $C$, ventral view of male genital structures; $D$, lateral view of male genital structures.

In color the entire body is rather uniformly pale green without definite markings of any kind.

The female last ventral segment (fig. $6, B$ ) is similar in type to that of $C$. unicolor, but is longer and more narrowed. The entire posterior margin is composed of two lobes, rather broadly rounded, which are formed by a Vshaped median notch, the sides of which are convexly rounded and after meeting, often overlap along the median line of incision. This incision extends one third of the way to the base. The whole surface of the segment is very rugose 
and striated, the striae running transversely on the anterior half and longitudinally on the posterior portion.

The male plates (fig. 6, $C$ ) are triangular, the apices are narrow and pointed. The plates are much shorter than the pygofers. The styles are elongate, narrowed to bluntly pointed apices. The aedeagus (fig. $6, D$ ) is long and slender with four slender terminal processes, two of which are short and two of which are quite long. The basal portion is bent dorsally and thickened and the apical half is bent dorsally.

Geographic Range. This is apparently the common broad-headed species of Chlorotettix in the Pacific Northwest and in California. It was originally described from Oregon and has since been recorded for California.

Distribution and Food Plants in California. Sonoma County: At Triniti, on June 4, 8, and August 14, 1943, adults were collected in miscellaneous sweepings.

Sonoma County: On June 7, 1944, at Geyserville a few adults were collected on Artemisia vulgaris by H. H. P. Severin. 


\section{LITERATURE CITED}

BALL, E. D.

1916. Some new species of Athysanus and related genera (Homoptera). Ent. News 27:173-76; 204-08.

DeLong, D. M.

1916. The leafhoppers or Jassoidea of Tennessee. Tennessee State Bd. Ent. Bul. 17:1-113.

1919. A synopsis of the genus Chlorotettix. Ohio State Univ. Bul. 23(15):1-31.

1923. Family Cicadellidae. In: Britton, Walter Everett, and D. M. DeLong. Guide to the insects of Connecticut. Part IV. The Hemiptera or sucking insects of Connecticut. Connecticut State Geol. and Nat. Hist. Survey Bul. 34:56-163.

1943. The Mexican leafhoppers of the genera Cloanthanus and Scaphytopius. (HomopteraCicadellidae). Lloydia 6(3):157-95.

1945. Some new species of Cloanthanus (Homoptera-Cicadellidae) from the eastern United States. Ohio Jour. Sci. 45(1):22-28.

DeLong, D. M., and R. H. Davidson.

1934. Some new species of Cicadellidae (Homoptera) from the United States. New York Ent. Soc. Jour. 42:221-24.

SaY, Thomas.

1831. Description of several new North American hemipterous insects belonging to the first family of the section Homoptera of Latreille. Acad. Nat. Sci. Philadelphia Jour. 6 (pt. II) :235-44.

Severin, H. H. P.

1947. Newly discovered leafhopper vectors of California aster-yellows virus. Hilgardia

Stål, Carolo. 17(16):511-23.

1864. Hemiptera nonnulla nova vel minus cognita. Soc. Ent. France Ann. 33:47-68.

Van Duzee, E. P.

1908. List of Hemiptera taken by W. J. Palmer, about Quinze Lake, P. Que., in 1907. Can. Ent. 40:109-16; 157-60.

1910. A revision of the American species of Platymetopius. Ent. Soc. Amer. Ann. 3(3): 214-31.

1914. A preliminary list of the Hemiptera of San Diego County, California. San Diego Soc. Nat. Hist. Trans. 2:1-57.

1917. Catalogue of the Hemiptera of America north of Mexico excepting the Aphididae, Coccidae and Aleurodidae. Univ. Calif. Publ. Entom. 2:1-902. 


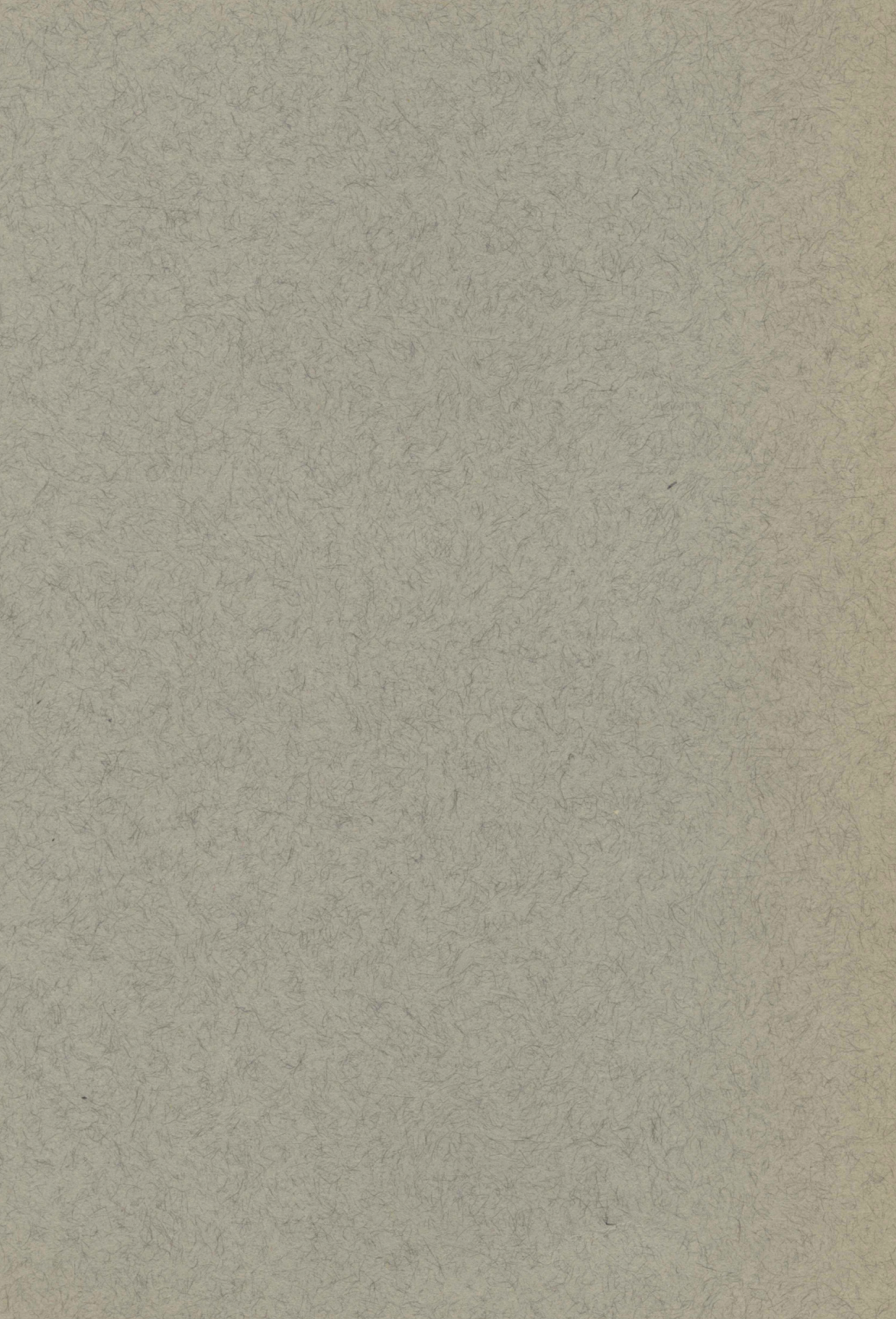

